REFLEKSI HUKUM

Jurnal Ilmu Hukum
p-ISSN 2541-4984 | e-ISSN 2541-5417

Volume 3 Nomor 1, Oktober 2018, Halaman 81-96

DOI: https://doi.org/10.24246/jrh.2018.v3.i1.p81-96

Open access at: http://ejournal.uksw.edu/refleksihukum

Penerbit: Fakultas Hukum Universitas Kristen Satya Wacana

\title{
PENERAPAN PRINSIP KEHATI-HATIAN DALAM PENYALURAN KREDIT (Studi Kasus di Bank BRI Cabang Semarang)
}

\author{
Willy Putra dan Haryati Widjaja \\ Fakultas Hukum Universitas Tarumanagara \\ Korespondensi: haryatiwijaya16@gmail.com
}

\begin{abstract}
Abstrak
Penerapan prinsip kehati-hatian dalam pemberian kredit merupakan hal yang paling penting karena bank merupakan salah satu faktor penting dalam menggerakan roda perekonomian Indonesia. Bunga dalam pemberian kredit merupakan pendapatan yang paling besar, sehingga dengan meningkatnya pemberian kredit, maka roda perekonomian Indonesia akan terus melaju ke arah yang lebih positif hingga terciptanya kesejahteraan masyarakat sebagaimana yang tercantum dalam alinea keempat Pembukaan Undang-Undang Dasar Negara Republik Indonesia Tahun 1945. Salah dalam memberikan kredit, maka akan berdampak pada kesejahteraan masyarakat. Oleh karena itu, bank harus selalu waspada dan berhati-hati dalam pemberian kredit dengan menerapkan prinsip 4P dan 5C, namun pada prakteknya masih banyak bank yang belum menerapkan prinsip kehati-hatian secara baik seperti yang terjadi pada Bank BRI di Semarang. Hal tersebut terjadi karena pihak bank tidak melakukan pengecekkan terhadap objek jaminan yang dijaminkan.
\end{abstract}

Kata Kunci: Prinsip; Kehati-hatian; Bank; BRI.

\begin{abstract}
The implementation of prudential principle in credit is the most important thing to do since bank is one of the influencing factors in Indonesia's economic wheel motion. Interest of credit is the biggest income, pointing out that giving credit increasingly will influence positively the Indonesia's economic wheel motion to create a society welfare as stated in Paragraph four of Preamble of the Indonesian Constitution. A wrong process in granting credit will affect the society welfare. In hence, bank should be more careful when it gives credit and it is strongly recommended to use $4 \mathrm{P}$ and $5 \mathrm{C}$ principle. Unfortunately, there are so many banks which do not implement the prudential principle perfectly yet in practice. For instance, a case of BRI branch Semarang that happened awhile ago because BRI did not check the collateral objects.
\end{abstract}

Keywords: Principle; Prudential; Bank; BRI. 


\section{PENDAHULUAN}

Setiap Negara yang dibentuk dan didirikan pasti mempunyai tujuan, tujuan Negara Kesatuan Republik Indonesia (NKRI) dapat dilihat dalam Pembukaan Undang-undang Dasar Negara Republik Indonesia Tahun 1945 (selanjutnya disebut dengan UUD NRI tahun 1945) alinea keempat yang berbunyi:

"Kemudian daripada itu untuk membentuk suatu Pemerintahan Negara Indonesia yang melindungi segenap Bangsa Indonesia dan seluruh tumpah darah Indonesia dan untuk memajukan kesejahteraan umum, mencerdaskan kehidupan bangsa dan ikut melaksanakan ketertiban dunia yang berdasarkan kemerdekaan, perdamaian abadi dan keadilan sosial."

Salah satu tujuan NKRI yang terdapat dalam alinea keempat tersebut adalah memajukan kesejahteraan umum yang mana salah satu cara untuk memajukan kesejahteraan umum ialah melalui pembangunan di bidang perekonomian. Bahwa dalam bidang perekonomian, Perbankan Indonesia mempunyai fungsi penting dalam pembangunan ekonomi. Selain fungsi utamanya sebagai intermediary, yang mempertemukan pemilik dana (surplus of fund) dengan pengguna dana (lack of fund), perbankan mempunyai peran strategis dalam mendorong perekonomian Indonesia, yaitu sebagai agent of development, agent of services dan agent of trust. ${ }^{2}$ Karena memiliki fungsi yang penting itulah maka lembaga perbankan merupakan salah satu pilar utama bagi pembangunan ekonomi nasional.

Kegiatan perbankan seperti pemberian kredit di Indonesia merupakan salah satu kegiatan yang utama sehingga pendapatan dari kredit berupa bunga merupakan pendapatan yang paling besar dibandingkan dengan pendapatan dari jasa-jasa diluar bunga kredit yang biasa disebut fee based income, oleh karena itu dalam penyaluran kredit harus dilakukan dengan prinsip kehati-hatian melalui analisa yang akurat dan mendalam, penyaluran yang tepat, pengawasan dan pemantauan yang baik, perjanjian yang sah dan memenuhi syarat hukum, pengikatan jaminan yang kuat dan dokumentasi perkreditan yang teratur dan lengkap. ${ }^{3}$ Berdasarkan UndangUndang Nomor 10 Tahun 1998 tentang perubahan atas Undang-Undang Nomor 7 Tahun 1992 tentang Perbankan (selanjutnya disebut dengan UU Perbankan) Kredit memiliki pengertian sebagai berikut:

"Penyediaan uang atau tagihan yang dapat dipersamakan dengan itu, berdasarkan persetujuan atau kesepakatan pinjam meminjam antara bank dengan pihak lain yang mewajibkan pihak peminjam melunasi utangnya setelah jangka waktu tertentu dengan pemberian bunga."4

Pembukaan Undang-Undang Dasar Negara Republik Indonesia Tahun 1945 alinea ke-4.

Lastuti Abubakar dan Tri Handayani, 'Telaah Yuridis Terhadap Implementasi Prinsip Kehati-hatian Bank dalam Aktivitas Perbankan Indonesia' (2017) 2 De Laga Lata 75, 90.

3 Nurwahjuni dan Abd Shomat, 'Four Eyes Principles dalam Pengelolaan Risiko Kredit Pada Bank' (2017) 31 Jurnal Yuridika 273, 275.

$4 \quad$ Pasal 10 ayat 11 UU No. 10 Tahun 1998 tentang Perbankan. 
Mengingat bahwa pemberian kredit merupakan kegiatan yang utama dari perbankan yang merupakan salah satu sumber pendapatan yang paling besar dibandingkan dengan jasa-jasa di luar bunga kredit, maka sebelum memberikan kredit kepada nasabah atau debitur atau pemohon kredit, pihak bank/ kreditur perlu melakukan analisa terlebih dahulu. Bentuk analisa yang dilakukan oleh bank terkait dengan pemberian kredit yaitu dengan menggunakan formula $4 \mathrm{P}$ dan $5 \mathrm{C}$.

Apabila nasabah atau debitur atau pemohon kredit telah memenuhi 4P dan 5C tersebut barulah dapat dikatakan layak untuk dikabulkan permohonan fasilitas kreditnya. Namun dalam prakteknya, banyak dijumpai bankbank yang belum menerapkan prinsip kehati-hatian dalam memberikan fasilitas kredit meskipun telah ditentukan bahwa sebelum fasilitas kredit diberikan kepada debitur, bank harus melakukan analisa terhadap calon debitur dengan menggunakan formula 4P dan 5C terlebih dahulu. Salah satu kasus bank yang lalai dalam menerapkan prinsip kehati-hatian adalah kasus Bank BRI cabang Semarang.

Kasus ini bermula dari Teguh yang mempunyai rencana untuk mengajukan kredit dengan menggunakan KTP Palsu dan Jaminan Palsu, kemudian Teguh menyuruh Muhhamad Romadhon alias Denny Yusmana untuk melakukan pengajuan kredit di Bank BRI Cabang Semarang Barat sebesar 40 (empat puluh) juta Rupiah dengan jaminan Sertipikat Hak Milik Nomor 02456 (selanjutnya disebut dengan SHM 02456) yang dibantu dengan Mundhi Mahardini alias Kistina Arumsari yang mengaku sebagai istri sah dari Denny Yusmana. Kemudian setelah Pihak Bank bertanya kepada Muhhamad Romadhon alias Denny Yusmana mengenai usaha yang dijalankan, Muhhamad Romadhon alias Denny Yusmana mengatakan menjalankan usaha percetakan undangan, dan tanpa melakukan pengecekan terhadap objek jaminan Pihak BRI Semarang melakukan pencairan Kredit pada tanggal 19 Desember 2016. ${ }^{5}$

Berdasarkan uraian kasus dan latar belakang tersebut di atas, penulis merasa tertarik untuk meneliti mengenai bagaimana penerapan prinsip kehati-hatian dalam pemberian kredit di bank yang kemudian penulis juga akan melakukan perbandingan pemberian kredit dengan beberapa bank lain yang ada di Indonesia.

Penelitian ini menggunakan metode penelitian yang bersifat normatif. Penelitian hukum normatif adalah suatu proses untuk menemukan suatu aturan hukum, prinsip-prinsip hukum maupun doktrin-doktrin hukum, untuk menjawab permasalahan hukum yang dihadapi. ${ }^{6}$ Bahan hukum yang digunakan oleh penulis adalah bahan hukum primer dan bahan hukum sekunder. ${ }^{7}$ Pengumpulan bahan hukum sekunder dilakukan dengan studi kepustakaan, yang dikumpulkan dengan

5 Muhamad Romadhon alias Denny Yusmana, Nomor 318/Pid.B/2017, Pengadilan Negeri Semarang, 13 Juni 2017.

$6 \quad$ Mukti Fajar dan Yulianto Achmad, Dualisme Penelitian Hukum dan Empiris (Pustaka Pelajar 2010) 34.

$7 \quad$ Peter Mahmud Marzuki, Penelitian Hukum Edisi Revisi (Prenamedia Group 2014) 181. 
membaca, mempelajari, serta mengidentifikasi, dan mengklasifikasi bahan tersebut hingga diperoleh bahan yang relevan dengan permasalahan yang dibahas. Penelitian hukum ini menggunakan pendekatan kasus (case approach).

\section{PEMBAHASAN}

\section{Prinsip Kehati-hatian dalam Pemberian Kredit}

Sebelum membahas mengenai prinsip kehati-hatian, penulis akan menjelaskan terlebih dahulu mengenai pengertian kredit itu sendiri. Istilah kredit disebutkan pada pasal 1 angka 11 UU Perbankan. Kredit adalah penyediaan uang atau tagihan yang dapat dipersamakan dengan itu, berdasarkan persetujuan atau kesepakatan pinjam-meminjam antara bank dan pihak lain yang mewajibkan pihak peminjam untuk melunasi utangnya setelah jangka waktu tertentu dengan pemberian bunga. ${ }^{8}$

Dari pengertian tersebut, dapat terlihat ada beberapa unsur mengenai kredit, antara lain: 9

a. Kepercayaan, yaitu keyakinan dari si pemberian kredit bahwa prestasi yang diberikannya baik dalam bentuk uang, barang atau jasa akan benar-benar diterimanya kembali dalam jangka waktu tertentu dimasa yang akan datang;

b. Tenggang waktu, yaitu suatu masa yang memisahkan antara pemberian prestasi dengan kontra prestasi yang akan diterimanya pada masa yang akan datang;

c. Degree of Risk, yaitu tingkat risiko yang akan dihadapi sebagai akibat dari adanya jangka waktu yang memisahkan antara pemberian prestasi dengan kontra prestasi yang akan diterima dikemudian hari. Semakin lama kredit diberikan berarti semakin tinggi pula tingkat risikonya.

d. Prestasi atau obyek kredit tidak saja diberikan dalam bentuk uang tetapi juga dalam bentuk barang atau jasa. Namun karena kehidupan ekonomi modern sekarang ini didasarkan kepada uang, maka transaksi-transaksi kredit dalam bentuk uanglah yang lazim dalam praktek perkreditan.

Unsur terpenting dalam suatu pemberian kredit adalah kepercayaan. Untuk memperoleh kepercayaan haruslah sampai pada suatu keyakinan sejauh mana konsep penilaian kredit dapat terpenuhi dengan baik.

Menurut Halle, jika seorang bankir memberikan pinjaman kepada perorangan atau perusahaan, bankir tersebut membutuhkan penilaian dalam bentuk analisis kredit untuk membantu menentukan risiko yang ada atau yang mungkin terjadi dari pinjaman yang diberikan, untuk itu analisis kredit amat penting, karena berguna untuk: 10

a. Menentukan risiko yang akan dihadapi oleh bank dalam memberikan kredit kepada seseorang atau badan usaha;

$8 \quad$ Rachmadi Usman, Aspek-Aspek Hukum Perbankan di Indonesia (PT Gramedia Pustaka Utama 2003) 236-237.

9 Thomas Suyatno, Et al., Dasar-dasar Perkreditan (PT Gramedia Pustaka Utama 2003) 14.

10 Halle, R.H., Credit Analys A Complete Guide (Jhon Wiley and Sons Inc. 1983) 53. 
b. Mengantisipasi pelunasan kredit tersebut karena bank telah mengetahui kemampuan melalui analisis cashflow usaha debitur;

c. Mengetahui jenis kredit, jumlah kredit dan jangka waktu kredit yang dibutuhkan oleh usaha debitur;

d. Mengetahui kemampuan dan kemauan debitur untuk melunasi kreditnya.

Oleh karena sangat pentingnya suatu analisis terhadap pemberian kredit maka terdapat suatu prinsip yang digunakan untuk analisis kredit yaitu prinsip kehati-hatian, prinsip kehatihatian adalah satu prinsip yang menegaskan bahwa bank dalam menjalankan kegiatan usaha baik dalam penghimpunan terutama dalam penyaluran dana kepada masyarakat harus sangat berhati-hati. Tujuan dilakukannya prinsip kehati-hatian agar bank selalu dalam keadaan sehat menjalankan usahanya dengan baik dan mematuhi ketentuan dan norma hukum yang berlaku di dunia perbankan. ${ }^{11}$ Prinsip kehati-hatian terdapat dalam Pasal 2 dan Pasal 29 ayat (2) UU Perbankan.

Sebelum bank memberikan kredit, bank harus melakukan penelitian dan penilaian terlebih dahulu terhadap calon nasabah atau debitur. Dalam melakukan penelitian terhadap calon nasabah, bank menerapkan $5 \mathrm{C}$, yang terdiri dari:

a. Character, berkaitan dengan sifat, watak, dan mora dari si pemohon kredit. b. Capacity, kemampuan calon nasabah debitur untuk mengelola kegiatan usahanya dan mampu melihat prospektif masa depan.

c. Capital, dalam hal ini bank harus terlebih dahulu melakukan penelitian terhadap modal yang dimiliki oleh pemohon kredit.

d. Collateral, jaminan untuk persetujuan pemberian kredit yang merupakan sarana pengaman (back up) atas risiko yang mungkin terjadi atas wanprestasinya nasabah di kemudian hari.

e. Condition of Economy, kondisi ekonomi secara umum dan kondisi sektor usaha pemohon kredit perlu memperoleh perhatian dari bank untuk memperkecil risiko yang mungkin terjadi yang diakibatkan oleh kondisi ekonomi tersebut. 12 Penilaian terhadap collateral dapat ditinjau dari 2 (dua) segi, yaitu:

1. Segi ekonomis, yaitu mengenai nilai ekonomis dari benda yang diagunkan; dan

2. Segi yuridis, yaitu menilai apakah aset atau benda yang dijadikan agunan memenuhi syarat-syarat yuridis;

Selain 5C, ada juga formula 4P yang digunakan dalam sebelum dilakukan pemberian kredit kepada nasabah, formula 4P tersebut terdiri dari:

a. Purpose, penilaian mengenai sasaran dan tujuan pemberian kredit;

b. Payment, sumber dan jadwal waktu pembayaran kredit;

11 Dutisa Monica Podung, 'Kredit Macet dan Penerapan Prinsip Kehatihatian Dalam Perbankan' (2016) 3 Lex Crimen 49, 50.

12 Hermansyah, Hukum Perbankan Nasional Indonesia (Prenamedia Group 2011) 63-64. 
c. Purpose, penilaian mengenai sasaran dan tujuan pemberian kredit;

d. Payment, sumber dan jadwal waktu pembayaran kredit;

e. Protection, mengatasi risiko apabila usaha debitur gagal;

f. Perspective, analisis kondisi perusahaan dan perspective mendatang. ${ }^{13}$

Prinsip Know Your Customer sebagai Pelaksanaan dari Prinsip Kehatihatian

Prinsip mengenal nasabah merupakan prinsip yang diterapkan untuk mengetahui identitas nasabah, memantau kegiatan transaksi nasabah termasuk pelaporan transaksi yang mencurigakan. ${ }^{14}$ Nindyo Pramono mengatakan bahwa:

"kurang tepat jika prinsip yang lepas dari prinsip kehati-hatian karena prinsip mengenal nasabah (Know Your Customer Principle) lebih tepat merupakan pelaksanaan dari prinsip kehati-hatian."15

Prinsip Know Your Cusstomer telah diatur dalam Peraturan Bank Indonesia (PBI). Pada tanggal 18 Juni 2001 BI telah mengeluarkan PBI No.3/10/ PBI/2001 tentang Penerapan Prinsip Mengenal Nasabah (Know Your Customer Principles) yang mana telah diubah dengan PBI No. 5/21/PBI/2003 yang mana kembali dilakukan penyempur-naan dengan adanya $\mathrm{PBI}$ No.11/28/PBI/2009 yang telah diubah dengan PBI No.14/27/PBI/2012 mengenai Penerapan Program Anti Pencucian Uang dan Pencegahan Pendanaan Terorisme bagi Bank Umum. PBI ini terkait dengan upaya pencegahan tindak pidana pencucian uang dan pencegahan pendanaan terorisme dengan menggunakan fasilitas dan produk perbankan.

Hal yang harus diperhatikan adalah dengan digantinya istilah Know Your Customer menjadi Customer Due Dilligence (CDD) yang artinya adalah kegiatan berupa identifikasi, verifikasi, dan pemantauan yang dilakukan bank untuk memastikan bahwa transaksi tersebut sesuai dengan profil calon nasabah, Walk In Customer (WIC), atau nasabah. ${ }^{16}$ Selain istilah tersebut ada juga istilah Enhanced Due Diligence (EDD) yang artinya adalah tindakan CDD lebih mendalam yang dilakukan bank pada saat berhubungan dengan calon nasabah, WIC, atau nasabah yang tergolong berisiko tinggi, termasuk politically exposed person, terhadap kemungkinan pencucian uang dan pendanaan terorisme. ${ }^{17}$

Seperti yang telah dijelaskan sebelumnya bahwa dalam Prinsip Mengenal Nasabah salah satunya terdiri dari prosedur manajemen risiko. Berdasarkan Pasal 1 ayat (3) Peraturan Otoritas Jasa Keuangan (POJK) No. 18/POJK.03/2016 Tentang Penerapan Manajemen Risiko bagi Bank Umum. Manajemen Risiko adalah serangkaian

13 Warman Djohan, Kredit Bank Alternatif Pembiayaan Dan Pengajuannya (PT. Mutiara Sumber Widya 2000) 108.

14 Asep Rozali, 'Prinsip Mengenal Nasabah (Know Your Customer) Dalam Praktik Perbankan' (2011) 24 Jurnal Wawasan Hukum 304, 307.

15 Ibid., 30.

16 Pasal 1 ayat 7 PBI No.14/27/PBI/2012 tentang Penerapan Program Anti Pencucian Uang dan Pencegahan Pendanaan Terorisme bagi Bank Umum.

17 Vide Pasal 1 ayat 8 PBI No.14/27/PBI/2012. 
metodologi dan prosedur yang digunakan untuk mengidentifikasi, mengukur, memantau, dan mengendalikan risiko yang timbul dari seluruh kegiatan usaha bank. ${ }^{18}$

Prosedur manajemen risiko diatur dalam PBI No. 5/8/2003 tentang Penerapan Manajemen Risiko bagi Bank Umum, yang terdiri dari:

a. Risiko kredit, risiko akibat kegagalan debitur dalam memenuhi kewajiban melunasi kredit pada bank. ${ }^{19}$

b. Risiko pasar, risiko kerugian pada posisi neraca serta pencatatan tagihan dan kewajiban di luar neraca yang timbul akibat pergerakan harga pasar. ${ }^{20}$

c. Risiko likuiditas, Risiko akibat ketidakmampuan Bank untuk memenuhi kewajiban yang jatuh tempo dari sumber pendanaan arus kas dan/atau dari aset likuid berkualitas. ${ }^{21}$

d. Risiko operasional, Risiko akibat tidak berfungsinya proses internal, kesalahan manusia, kegagalan sistem, dan/atau adanya kejadiankejadian eksternal yang mempengaruhi operasional bank. ${ }^{22}$

e. Risiko hukum, risiko akibat tuntutan hukum dan/atau kelemahan aspek yuridis. ${ }^{23}$

f. Risiko stratejik, risiko akibat ketidaktepatan dalam pengambilan suatu keputusan stratejik serta kegagalan dalam mengantisipasi perubahan lingkungan bisnis. ${ }^{24}$

g. Risiko kepatuhan, risiko akibat bank tidak mematuhi dan/atau tidak melaksanakan peraturan perundang-undangan dan ketentuan. ${ }^{25}$

h. Risiko reputasi, risiko akibat menurunnya tingkat kepercayaan stakeholder yang bersumber dari persepsi negatif terhadap bank. ${ }^{26}$

Dalam melakukan penerapan

Prinsip KYC bank memiliki kewajiban pokok yaitu:

a. Menetapkan kebijakan penerimaan nasabah;

b. Menetapkan kebijakan dan prosedur dalam mengidentifikasi nasabah;

c. Menetapkan kebijakan dan prosedur pemantauan terhadap rekening dan transaksi nasabah;

d. Menetapkan kebijakan dan prosedur manajemen risiko.

Nasabah sendiri dibagi ke dalam 4 golongan yang memiliki keperluan dokumennya masing-masing:

a. Nasabah perorangan

Dokumen yang diperlukan meliputi: identitas nasabah (nama, alamat domisili, tempat dan tanggal lahir, kewarganegaraan); keterangan mengenai pekerjaan, specimen tanda tangan dan keterangan sumber

\footnotetext{
18 Pasal 1 ayat 3 POJK No.18/POJK.03/2016 tentang Penerapan Manajemen Risiko bagi Bank Umum.

19 Ikatan Bankir Indonesia, Manajemen Risiko I: Mengindentifikasi Risiko Pasar, Operasional, dan Kredit Bank (Gramedia Pustakan Utama 2015) 67.

Sumar'in, Konsep Kelembagaan Perbankan Syariah,(Graha Ilmu 2012) 111.

Vide Pasal 1 ayat (6) POJK No.18/POJK.03/2016.

Vide Pasal 1 ayat (7) POJK No.18/POJK.03/2016.

Vide Pasal 1 ayat (9) POJK No.18/POJK.03/2016.

Vide Pasal 1 ayat (11) POJK No.18/POJK.03/2016.

Vide Pasal 1 ayat (8) POJK No.18/POJK.03/2016.

Vide Pasal 1 ayat (10) POJK No.18/POJK.03/2016.
} 
dana dan penggunaan dana.

b. Nasabah Perusahaan

Dokumen yang dibutuhkan adalah akta pendirian/anggaran dasar, izin usaha, struktur manajemen perusahaan, dokumen identitas pengurus yang mewakili perusahaan, nama, specimen tanda tangan, kuasa yang ditunjuk untuk melakukan hubungan usaha dengan bank, NPWP, Keterangan sumber dana dan tujuannya.

c. Nasabah Kelembagaan

Merupakan lembaga pemerintah, lembaga internasional, dan perwakilan asing yang dibutuhkan hanya nama, specimen tanda tangan, surat penunjukan bagi yang berwenang mewakili.

d. Nasabah Bank

Yang dibutuhkan akta pendirian/ anggaran dasar bank, izin usaha, nama, specimen tandatangan, surat kuasa melakukan hubungan usaha dengan bank.

Berdasarkan uraian yang telah disampaikan mengenai prinsip kehatihatian yang digunakan dalam pemberian kredit, maka dalam kasus bank BRI Semarang, pihak bank tidak menerapkan prinsip kehati-hatian dengan baik, hal tersebut dapat dilihat dari pihak bank yang tidak melakukan pengecekkan terhadap sertifikat tanah yang diagunkan pada saat pengajuan kredit dan kemudian berdasarkan sertipikat palsu yang dijaminkan pihak bank BRI mencairkan kredit yang diajukan oleh Muhhamad Romadhon alias Denny Yusmana.
Adapun prosedur pemberian dan penilaian kredit oleh dunia perbankan secara umum Menurut Kasmir:27

a. Pengajuan Berkas

Pengajuan proposal kredit berisi antara lain, latar belakang, maksud dan tujuan, besarnya kredit dan jangka waktu, cara pengembalian kredit dan jaminan kredit. Lampiran proposalnya berupa, akta notaris, surat keterangan usaha, NPWP, neraca dan laporan rugi laba 3 tahun terakhir, bukti diri dari pimpinan perusahaan, foto copy sertipikat jaminan, foto copy $\mathrm{ktp}$, dan surat nikah.

b. Penyelidikan bekas pinjaman

Tujuannya, untuk mengetahui apakah berkas pinjaman yang diajukan sudah lengkap sesuai dengan persyaratan dan sudah benar atau belum Jika menurut pihak perbankan belum lengkap atau cukup maka nasabah diminta untuk segera melengkapinya.

c. Wawancara I

Merupakan Penyelidikan kepada calon peminjam dengan langsung berhadapan dengan calon peminjam.

e. On The Spot

Merupakan kegiatan pemeriksaan ke lapangan dengan meninjau berbagai obyek yang akan dijadikan usaha atau jaminan.

f. Wawancara II

Merupakan kegiatan perbaikan berkas, jika mungkin ada kekurangan pada saat setelah dilakukan on the spot di lapangan.

27 Kasmir, Dasar-dasar Perbankan (PT RajaGrafindo Persada 2018) 100. 
g. Keputusan Kredit

Keputusan kredit dalam hal ini adalah menentukan apakah kredit akan diberikan atau ditolak, jika diterima, maka akan dipersiapkan administrasinya.

h. Penandatangan akad kredit/ perjanjian lainnya

Kegiatan ini merupakan kelanjutan dari diputuskannya kredit, maka sebelum kredit dicairkan maka terlebih dahulu calon nasabah menandatangani akad kredit.

i. Realisasi Kredit

Diberikan setelah penandatanganan surat-surat yang diperlukan dengan membuka rekening giro atau tabungan di bank yang bersangkutan.

j. Penyaluran/penarikan

Pencairan atau pengambilan uang dari rekening sebagai realisasi dari pemberian kredit.

Proses pengajuan pada kredit yang diberikan oleh bank $\mathrm{BCA}^{28}$ adalah sebagai berikut:

a. Nasabah mengajukan permohonan kredit ke bank BCA disertai dengan dokumen pendukung yang meliputi: 1. Nasabah perorangan:

(i) Identitas diri (apabila sudah menikah diminta buku nikah dan identitas pasangan)

(ii) Kartu Keluarga

(iii) NPWP

(iv) Jaminan

2. Nasabah Badan Hukum:

(i) Akta pendirian, SK pengesahan dari Menkumham; (ii) KTP Pengurus;

(iii) NPWP badan hukum dan direksi yang mewakili pada saat tanda tangan;

(iv) Laporan neraca keuangan;

b. Tim analis kredit melakukan analisa terhadap:

1. Data debitur;

2. Jaminan yang diberikan (mengenai kepemilikkan, status hak atas tanah);

3. Taksiran jaminan yang diajukan sesuai dengan plafond kredit yang diajukan atau tidak;

Apabila dinilai tidak berisiko, maka oleh tim analisa kredit akan memberikan memo kepada legal. Apabila legal telah mengecek kebenaran jaminan yang diberikan, dan kebenaran identitas debitur, maka akan dilakukan pengikatan jaminan dan pembuatan perjanjian kredit, antara debitur dengan bank selaku kreditur.

Proses pengajuan kredit yang kedua adalah pada bank Bukopin yang dijelaskan sebagai berikut 29

a. Analys Officer Sales (AOS) akan memasukan data identitas Debitor ke dalam Internal Control System Application System (ICS);

b. Credit Investigator (CI) memeriksa Sistem Informasi Debitur (SID) BI, apabila memenuhi kualifikasi debitur maka akan diproses kepada tahapan selanjutnya dengan laporan kepada Direktur Keuangan. Apabila setuju dengan laporan tersebut maka AOS akan memasukan data Debitur ke dalam

28 Hasil wawancara dengan Clara selaku staff analis kredit BCA, dilakukan pada hari Rabu 27 Februari 2019, Pukul 10.00 WIB.

29 Bukopin, 'Ketentuan Prosedur Kredit Komersial' (SE No. 186/DIR/XII/2017). 
permohonan;

c. CI akan melakukan pemeriksaan transaksi, pemeriksaan perusahaan dan individu, terutama terkait dengan plafon credit, penjaminan aset, dan akan memberikan pendapat akan penilaian terhadap obyek yang dijaminkan;

d. Legal akan membuat analisa hukum, analisa kontrak, dan batas maksimum pemberian kredit;

e. Analys Officer (AO) akan melakukan evaluasi dan analisis kredit dari kelayakan pemohon, AO akan mengajukan proposal, perhitungan kebutuhan kredit, neraca keuangan dan kelayakan kredit. AO juga akan memberikan analisis terhadap risiko kredit. Apabila dibutuhkan AO juga dapat melakukan validasi data yang diberikan oleh $A O S$;

f. Divisi Pemenuhan dan Manajemen Risiko akan memberikan pendapat terhadap pemenuhan dan manajemen Risiko;

g. AO akan membuat draft perjanjian kredit, apabila dapat diproses lebih lanjut maka akan di diskusikan dengan sekretaris bagian komite pemberian kredit, yang mana nantinya akan menghasilkan keputusan apakah kredit tersebut disetujui atau ditolak yang nantinya akan berbentuk Surat Penegasan Seputar Kredit (SPPK).

h. AOS akan memberikan SPPK tersebut kepada debitor untuk di tandatangani;

i. AOS dan Legal akan melakukan Pengikatan Kredit dengan Debitur; j. Proses Pemberian Kredit akan dilakukan di Bagian Dukungan Kredit.

Sedangkan proses pengajuan kredit pada bank Panin ${ }^{30}$ akan dijelaskan sebagai berikut:

a. pemohon mengajukan permohonan kredit ke bank Panin yang kemudian setelah berkas diajukan tim $A O$ akan melakukan proses review data, terkait dengan jaminan yang diagunkan, misalnya tanah, maka $A O$ akan melakukan

b. Selanjutnya akan dilakukan taksasi terhadap jaminan dan diperiksa oleh BI;

c. Selanjutnya akan dilakukan taksasi terhadap jaminan dan diperiksa oleh BI;

d. Setelah dilakukan pengecekkan dan semua data yang diberikan sudah tervalidasi, maka $A O$ akan membuat memo rencana kredit yang berisi limit kredit yang diberikan kepada komite kredit.

e. Apabila disetujui, maka akan dibuatkan offering letter, sedangkan apabila tidak disetujui komite kredit, maka akan dibuatkan surat penolakan terhadap fasilitas kredit yang dimohonkan.

f. Setelah pemohon kredit setuju dengan nilai fasilitas kredit yang diberikan, maka selanjutnya akan dibuatkan instruksi pengikatan agar segera dibuatkannya perjanjian kredit dan pengikatan jaminan.

g. Setelah adanya perjanjian kredit dan pengikatan jaminan, bagian hukum akan menerbitkan legal

30 Paninbank, 'Materi Pelatihan Kredit Bank Panin' (Paninbank 2013). 
closing memo untuk selanjutnya diserahkan kepada bagian control exposure. Setelah closing memo diterima, akan dilakukan pengecekkan dan apabila semua telah memenuhi standar akan diterbitkan memorandum penyediaan fasilitas.

Berdasarkan data-data yang penulis dapatkan dari 3 (tiga) bank sebagai pembanding dalam proses penyaluran kredit, penulis berpandangan bahwa terhadap proses penyaluran kredit yang dilakukan oleh BCA, BCA merupakan salah satu bank yang menerapkan KYC, karena terhadap data diri pemohon, dilakukan penilaian terhadap nasabah dan pengecekan terkait jaminan yang dijadikan sebagai agunan maupun data diri oleh tim analys kredit. Dalam hal pemohon adalah perseorangan, maka tim analis akan melakukan pengecekkan mulai dari kartu identitas, NPWP, bahkan sampai dengan spesimen tanda tangan yang diberikan dicocokan dengan tanda tangan di KTP, sedangkan dalam hal pemohon merupakan badan hukum, maka bank BCA akan melakukan pengecekkan terkait dengan jenis usaha, direktur dan komisaris yang menjabat agar memastikan bahwa pengurus yang bersangkutan masih berwenang pada saat penandatanganan perjanjian kredit yang kemudian sebagai bentuk pengecekan bank BCA akan meminta akta pendirian dan akta perubahan terakhir disertai dengan identitas pengurus perusahaan yang masih berwenang, NPWP Perusahaan, SIUP, TDP, atau yang sekarang telah diganti dengan NIB. Kemudian setelah dilakukannya pengecekan akan ditindaklanjuti dengan dibuatkannya legal memo kepada tim legal bahwa data diri serta jaminan yang diagunkan memang sudah sesuai datanya dan kemudian dari legal memo yang diterbitkan tim analys kredit, pihak legal dari bank BCA akan segera menindaklanjutinya dengan dibuatkan letter dan pembuatan perjanjian kredit. Sehingga untuk proses persetujuan kredit yang diberikan oleh BCA sangatlah tidak mudah karena melalui proses yang rumit dan sangat teliti.

Sedangkan terhadap pemberian fasilitas kredit di bank Panin, juga sudah menerapkan prinsip KYC dengan baik, hal tersebut dapat dilihat dari adanya review data dan pengecekan agunan secara on the spot yang dilakukan oleh $A O$. Kemudian adanya proses BI Checking oleh tim informasi dan administrasi, yang kemudian apabila semuanya telah di approve, maka akan dilakukan pengecekkan antara agunan yang dijaminkan dengan fasilitas kredit yang diajukan.

Proses persetujuan kredit fasilitas kredit pada bank Bukopin juga sudah menerapkan $\mathrm{KYC}$, hal tersebut dapat dilihat dari proses kredit yang panjang dan cukup lama, yang dimulai dari $A O$ memasukan data ke dalam ICS, yang kemudian akan diperiksa oleh (CI) dalam sistem informasi debitur BI setelah itu CI akan melakukan pemeriksaan transaksi, pemeriksaan perusahaan dan individu, terutama terkait dengan plafon kredit,penjaminan aset, dan akan memberikan pendapat akan penilaian terhadap obyek yang dijaminkan. Keseluruhan hal tersebut jelas telah menunjukan bahwa memang adanya penerapan KYC, namun tidak 
hanya sampai disana karena bank Bukopin memerlukan waktu untuk meneliti lebih lanjut mengenai data identitas serta agunan yang dijaminkan yang nantinya legal akan membuat analisa hukum, analisa kontrak, dan batas maksimum pemberian kredit, kemudian $A O$ akan melakukan evaluasi dan analisis kredit dari kelayakan pemohon akan memberikan analisis terhadap risiko kredit kemudian barulah $A O$ akan membuat draft perjanjian kredit, apabila dapat diproses lebih lanjut maka akan di diskusikan dengan sekretaris bagian komite pemberian kredit, yang mana nantinya akan menghasilkan keputusan apakah kredit tersebut disetujui atau ditolak yang nantinya akan berbentuk Surat Penegasan Seputar Kredit (SPPK) yang akan diberikan kepada Debitor untuk ditandatangani dan setelah itu baru akan dibuatkan Pengikatan Kredit.

\section{Penerapan Prinsip Kehati-hatian dalam Penyaluran Kredit (Studi Kasus di Bank BRI Cabang Semarang)}

Bisnis perbankan merupakan bisnis yang penuh resiko, karena sebagian besar aktivitasnya mengandalkan dana titipan dari masyarakat, baik dalam bentuk tabungan, giro maupun deposito. Bank harus meyakinkan masyarakat jika dana yang dititipkannya aman dan dapat membawa keuntungan bagi masyarakat. ${ }^{31}$ Oleh karena itu, untuk mendapatkan

Sebagaimana telah dijelaskan sebelumnya mengenai peranan agunan kepercayaan dari masyarakat, bank haruslah senantiasa berhati-hati.

Prinsip kehati-hatian dalam penyaluran kredit merupakan hal yang penting, karena apabila sebuah bank tidak dapat menerapkan prinsip kehatihatian dengan baik, maka akan berdampak pada kepercayaan masyarakat terhadap kinerja bank. Dalam UU Perbankan, lebih tepatnya di Pasal 2 dikatakan bahwa perbankan Indonesia dalam melakukan usahanya berasaskan demokrasi ekonomi dengan menggunakan prinsip kehati-hatian. Sehingga sudah seharusnya bank menerapkan prinsip kehati-hatian. Salah satu bentuk penerapan prinsip kehati-hatian dalam praktek dunia perbankan adalah dengan menerapkan prinsip KYC yang sekarang telah disempurnakan menjadi CDD. Berdasarkan Pasal 8 dan Penjelasannya UU Perbankan implementasi prinsip kehati-hatian diterjemahkan sebagai keyakinan bank berdasarkan analisis yang mendalam atas itikad baik dan kemampuan, serta kesanggupan nasabah debitur untuk melunasi utangnya. ${ }^{32}$ Pasal 8 UU Perbankan menegaskan bahwa agunan merupakan salah satu unsur dalam pemberian kredit. Sehingga untuk meminimalkan risiko terjadinya kredit macet, pada umumnya bank menekankan terhadap ketersediaan jaminan

baik jaminan pokok maupun jaminan tambahan.

dalam pemberian fasilitas kredit, maka terhadap agunan yang diberikan oleh

31 Rio Andang Sanjaya, Paramita Prananingtyas, Siti Mahmudah., 'Prinsip Kehati-hatian Pada Pemberian Kredit oleh Pejabat Bank (Studi Kasus Pemberian Kredit Oleh PT. BNI Tbk Kepada PT. Guna Inti Permata' (2016) 5 Diponegoro Law Journal 5, 22.

32 Lastuti Abubakar dan Tri Handayani, Op. Cit., 76. 
debitur harus dilakukan pengecekkan guna mencegah terjadinya kredit macet dengan jaminan yang tidak pasti. Namun permasalahan timbul pada saat bank melakukan kesalahan umum.

Kesalahan umum yang dimaksud antara lain: terlambat memberikan putusan kredit, terlalu rumit prosedurnya, terlalu cepat memutus, memutus karena tekanan, memutus tanpa data yang lengkap, jumlah putusan kurang, jumlah putusan berlebihan, terlalu memanjakan nasabah, tidak memecahkan kesulitan nasabah. ${ }^{33}$

Juga beberapa kesalahan yang justru dilakukan oleh nasabah sendiri seperti terlambat mengajukan kredit, terlalu yakin akan kemampuannya, kurang terbuka pada bank. Salah penggunaan kredit, kurang pengalaman dalam usaha, menyimpangkan penggunaan kredit, ketidak harmonisan pemilih dan masalah perburuhan. ${ }^{34}$

Kesalahan yang dilakukan oleh nasabah memang seharusnya tidak dapat ditolelir, mengingat apabila telah dilakukannya pemeriksaan secara detail dan sesuai dengan prosedur yang ada maka kelalaian dari nasabah dapat ditemukan lebih awal sehingga tidak dapat diterima proses pengajuan kreditnya.

Dalam kasus yang terjadi pada pemberian kredit oleh BRI sebagaimana dijelaskan sebelumnya menunjukan bahwa adanya kelalaian yang terjadi dalam penerapan KYC yang merupakan bentuk pelaksanaan dari prinsip kehatihatian.

Kelalaian terjadi ketika awal proses Pengajuan kredit untuk melakukan penerapan 5C, ketika penilaian terhadap Character yang mana KTP yang digunakan adalah KTP palsu. Hal ini memang merupakan hal yang sulit dibuktikan, seperti dalam kasus ini Pihak BRI telah melakukan prosedur pemberian kredit yang di dalam KTP yang dilampirkan pada saat pengajuan pinjaman. 35

Beberapa hari kemudian pihak BRI datang untuk melakukan survey di alamat yang diberikan dan debitur mengaku memiliki usaha kelontong, cetak undangan, dan ternak ikan nila. Kelalaian BRI disini adalah ketika BRI melakukan survey apakah melihat ada toko kelontong, undangan dan ternak ikan nila, kemudian apakah BRI sempat melakukan konfirmasi mengenai identitas ke tetangga sekitar dan menurut pengakuan BRI pada saat pengajuan awal memang identitas yang muncul sesuai namun hanya bagian fotonya yang tidak nampak hal ini seharusnya sudah dapat dicurigai karena hal yang sulit untuk dipalsukan memang foto dari nasabah.

Kemudian mengenai Collateral, yaitu SHM 02456, BRI sama sekali tidak melakukan pemeriksaan terhadap jaminan yang dijaminkan tersebut pada saat pengajuan kredit di awal dengan

33 H. Chairil M. Noor, Manajemen Kredit Bank Umum dan Bank Perkreditan Rakyat (Quantum Exprert 2013) 17.

$34 \quad$ Ibid.

35 Muhammad Romadhon als. Denni Yusmana bin Rozikan Nomor 318/Pid.B/2017/PN.SMG., Pengadilan Negeri Semarang, 13 Juni 2017. 
alasan tidak punya aplikasi sistem komputernya, padahal dapat dilakukan pengecekan melalui BPN namun hal ini tidak dilakukan dengan alasan pinjaman di bawah Rp. 100.000.000,(seratus juta Rupiah). Sehingga jelas bahwa dalam kasus ini prinsip 5C dalam pemberian kredit hanya sebuah formalitas yang dilakukan untuk memenuhi kebutuhan administrasi yang mana seharusnya bank berhatihati dalam memberikan Pinjaman kredit. Sebelum memberikan fasilitas kredit BRI seharusnya melakukan pengecekan on the spot. On the spot haruslah meliputi kondisi kemampuan debitur, kegiatan usaha debitur, dan karakter debitur. Tidak hanya melakukannya berdasarkan foto lokasi yang diberikan melainkan melakukan secara cross check secara benar-benar mengenai data yang diajukan debitur sudah benar atau belum. ${ }^{36}$

Lebih lanjut apabila mengacu pada KYC yang telah disempurnakan dan diganti istilahnya menjadi CDD sebagai bentuk pelaksanaan penerapan prinsip kehati-hatian memiliki salah satu prosedur yaitu prosedur manajemen risiko. Namun meskipun telah disempurnakan tetap saja kelalaian kerap terjadi. Hal tersebut dapat dilihat dari kasus ini yang sama sekali tidak mencerminkan bahwa adanya manajemen risiko yang dilakukan, karena pemeriksaan nasabah tidak dilakukan secara mendalam hanya dilakukan pemeriksaan sekedarnya.

Kemudian yang menjadi permasalahan berikutnya adalah dam- dari kelalaian tersebut. Dengan lalainya penerapan KYC dalam pemberian kredit maka tidak akan teridentifikasi apabila adanya supicious transaction, memang dalam kasus ini nominal yang ajukan hanya sebesar Rp. 40.000.000,- (empat puluh juta Rupiah). Namun hal terpenting yang perlu diingat adalah, dalam peraturan yang BI tidak sebutkan bahwa penerapan KYC dilakukan apabila kredit yang diajukan harus dengan batasan nominal tertentu. Bukan berarti dengan tidak disebutkannya batasan nominal tertentu pihak Bank dapat mengabaikan untuk melakukan prinsip KYC dengan baik.

Dengan lalainya bank tersebut dalam menerapkan prinsip KYC, Pasal 18 PBI No. 3/10/PBI/2001 menyebutkan bahwa bagi pelanggaran terhadap beberapa ketentuan dalam PBI tersebut dikenakan sanksi administratif berupa kewajiban membayar sebesar Rp1 juta per hari keterlambatan dan setinggitingginya Rp30 juta. Hanya sebatas sanksi administratif berupa denda. Seharusnya aturan ini dipertegas, misalnya memberikan sanksi berupa pemberhentian kerja terhadap jajaran dari pihak Bank yang tidak melaksanakan dengan baik prinsip KYC ini sehingga menimbulkan kerugian terhadap Bank, terutama dalam kasus ini adalah BRI, yang mana seharusnya lebih mendalam dalam melakukan KYC karena dapat menimbulkan kerugian keuangan negara lebih mendalam dalam melakukan KYC karena dapat menimbulkan kerugian keuangan negara

36 Paundra Kartika MS, Budiharto, Hendro Saptono, 'Dugaan Adanya Pelanggaran Prinsip kehatihatian dalam Penyaluran Kredit Fiktif (Studi Kasus Putusan Mahkamah Agung Nomor 2313/K/Pid. Sus /2012)' (2016) 5 Diponegoro Law Journal 6, 10. 
Memang dengan adanya sanksi yang diberikan sesuai dengan pasal 18 PBI No. 3/10/PBI/2001, sudah dapat dikatakan telah terakomodir namun pada kenyataannya sanksi yang diberikan sepertinya belum cukup, mengingat dalam perkembangannya telah diubah menjadi CDD, yang notabene lebih bersifat preventif daripada proses KYC sebelumnya.

\section{PENUTUP}

Bahwa berdasarkan uraian yang telah disampaikan, maka dapat disimpulkan bahwa dalam prakteknya masih banyak bank yang belum menerapkan prinsip kehati-hatian dalam penyaluran kredit dengan baik, hal tersebut terbukti melalui kasus BRI cabang Semarang. BRI telah lalai dalam menilai objek jaminan atau agunan yang diberikan oleh debitur sehingga terjadi kasus sebagaimana yang terdapat dalam putusan Nomor 318/PN.SMG/2017.

\section{DAFTAR BACAAN}

\section{Buku}

Djohan, W., Kredit Bank Alternatif Pembiayaan dan Pengajuannya (PT Mutiara Sumber Widya 2000).

Fajar, M., dan Yulianto A., Dualisme Penelitian Hukum dan Empiris (Pustaka Pelajar 2010).

H., Halle R., Credit Analys A Complete Guide (Jhon Wiley and Sons Inc 1983).

Hermansyah, Hukum Perbankan Nasional Indonesia (Prenamedia Group 2011).
Ikatan Bankir Indonesia, Manajemen Risiko I: Mengindentifikasi Risiko Pasar, Operasional, dan Kredit Bank (PT Gramedia Pustaka Utama 2015).

Kasmir, Dasar-Dasar Perbankan (PT Raja Grafindo Persada 2018).

Marzuki, Peter M., Penelitian Hukum Edisi Revisi (Prenamedia Group 2014).

Noor, H. Chairil M., Manajemen Kredit Bank Umum dan Bank Perkreditan Rakyat (Quantum Exprert 2013).

Sumar'in, Konsep Kelembagaan Perbankan Syariah (Graha Ilmu 2012).

Suyatno, T., Dasar-Dasar Perkreditan (PT Gramedia Pustaka Utama 2003).

Usman, R., Aspek-Aspek Hukum Perbankan di Indonesia (PT Gramedia Pustaka Utama 2003).

\section{Artikel Jurnal}

Abubakar, L., dan Tri H., 'Telaah Yuridis Terhadap Implementasi Prinsip Kehati-hatian Bank dalam Aktivitas Perbankan Indonesia' (2017) 2 De Laga Lata.

Nurwahjuni, dan Shomat, Abd., Four Eyes Principles dalam Pengelolaan dan Penerapan Prinsip Kehatihatian dalam Perbankan' (2016) 3 Jurnal Lex Crimen.

Rozali, A., 'Prinsip Mengenal Nasabah (Know Your Customer) Dalam Praktik Perbankan' (2011) 24 Jurnal 
Wawasan Hukum.

Sanjaya, Rio Andang Paramita P., Siti M., 'Prinsip Kehati-hatian Pada Pemberian Kredit oleh Pejabat Bank (Studi Kasus Pemberian Kredit Oleh PT. BNI Tbk Kepada PT. Guna Inti Permata)' (2016) 5 Diponegoro Law Journal.

MS, Paundra Kartika B.,, Hendro S., 'Dugaan Adanya Pelanggaran Prinsip kehati-hatian dalam Penyaluran Kredit Fiktif (Studi Kasus Putusan Mahkamah Agung Nomor 2313/K/Pid.Sus / 2012)' (2016) 5 Diponegoro Law Journal.

Podung, Dustica Monica, 'Kredit Macet Risiko Kredit Pada Bank (2017) 31 Jurnal Yuridika.

\section{Putusan Pengadilan}

Putusan Pengadilan Negeri Semarang Nomor 318/Pid.B/2017/PN. SMG.

\section{Peraturan Perundang-Undangan}

Undang-Undang Dasar Negara Republik Indonesia Tahun 1945.

Undang-Undang Republik Indonesia Nomor $10 \quad$ Tahun 1998 tentang Perbankan.

Peraturan Bank Indonesia Nomor 3/10/PBI/2001Tahun 2001 tentang Penerapan Prinsip Mengenal Nasabah (Know Your Customer Principle).

Peraturan Bank Indonesia Nomor 14/27/PBI/2012 Tahun 2012 tentang Penerapan Program Anti Pencucian Uang dan Pencegahan Pendanaan Terorisme bagi Bank Umum.
Peraturan Otoritas Jasa Keuangan Nomor 18/POJK.03/2016 tentang Penerapan Manajemen Risiko bagi Bank Umum.

\section{Lain-lain}

Bukopin, 'Ketentuan Prosedur Kredit Komersial' (SE No. 186/DIR/XII/ 2017).

Paninbank, 'Materi Pelatihan Kredit Bank Panin' (Paninbank 2013). 